\title{
Modulation of bisquaternary ammonium agents effect on model biomembranes by complex formation with an organic anion
}

\author{
O. V. Vashchenko, V. A. Pashynska', M. V. Kosevich', V. D. Panikarskaya, \\ L. N. Lisetski
}

Institute for Scintillation Materials NAS of Ukraine 60, Prospekt Lenina, Kharkiv, Ukraine, 61085

${ }^{1}$ Institute for Low Temperature Physics and Engineering NAS of Ukraine 47, Prospekt Lenina, Kharkiv, Ukraine, 61103

olga_v@isma.kharkov.ua

\begin{abstract}
Aim. To study membranotropic activity modulation of bisquaternary ammonium compounds (BQAC) decamethoxinum and aethonium determined by their interaction with dihydroxybenzoic acid (DHB) organic anion. Methods. Differential scanning calorimetry, mass spectrometry. Results. Doping phospholipid membranes with individual BQAC or DHB leads to a considerable decrease in the membrane melting temperature. At the same time, when BQAC and DHB are introduced together, a certain increase in the membrane melting temperature is observed, implying non-additivity of their action and incorporation of their complexes into the membranes. Conclusions. DHB decreases the efficiency of BQAC destabilizing action on the membranes, i. e. DHB is a modulator of their membranotropic activity. A possible molecular mechanism of the modulation consists in the compensation of charges of the BQAC dications by organic $D H B$ anions on the complex formation; parameters of the complex interaction with the membrane structures differ from those of individual ionic compounds.
\end{abstract}

Key words: membranotropic agents, phospholipid membranes, bisquaternary ammonium compounds, dihydroxybenzoic acid, activity modulation, differential scanning calorimetry.

Introduction. It is known that the efficiency of pharmacological preparations is determined by their main active compound and the modulation of activity by other substances present in the pharmaceutical form. The present investigation was aimed at modulating influence of antimicrobial preparations based on bisquarternary ammonium compounds (BQAC) by their binding to organic anions. One of the main mechanisms of activity of membranotropic BQAC,

(C) Institute of Molecular Biology and Genetics NAS of Ukraine, 2010 which are the cation surface active compounds (surfactants), is believed to be their binding to the cytoplasmic membranes of microorganisms, resulting in their malfunction [1]. In the series of our previous publications [2-4], dedicated to systematic study on the molecular mechanisms of activity of the BQAC-based antimicrobial preparations, decamethoxinum and aethonium (Fig.1, $a, b$ ), we showed that these preparations interacted with model phospholipid membranes and formed stable non-covalent complexes with phospholipids. The 


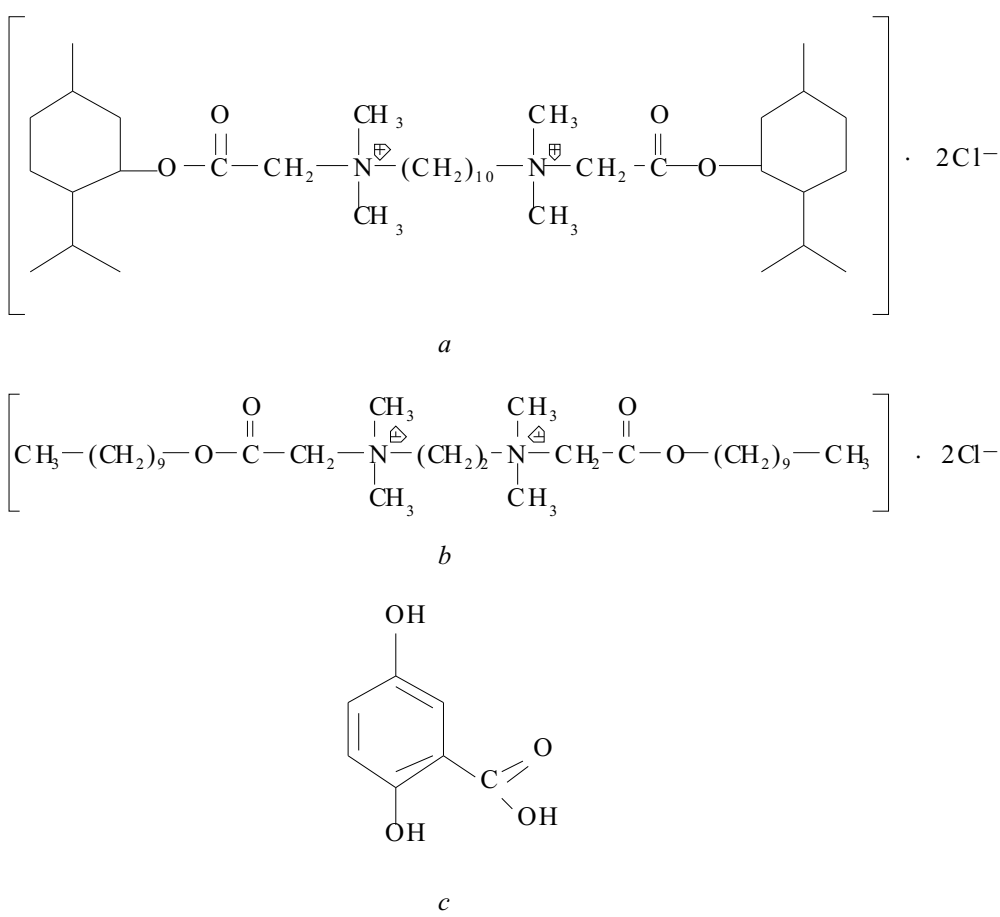

Fig. 1. Structural formulas of dichlorides of BQAC of decamethoxinum $(a)$, aethonium $(b)$, and 2.5-dihydroxybenzoic acid $(c)$ further mass-spectrometry experiments revealed that an anion of organic 2, 5-dihydroxybenzoic acid (DHB) is able to replace a counter-ion of chloride, thus forming a stable complex with decamethoxinum dication. This fact allowed us to suppose a possibility of formation of such complexes as a result of joint action of these two substances on phospholipid membranes, as well as to assume an effect of binding BQAC dications to DHB organic anions on their membranotropic activity. To check this assumption, a model system was selected as water dispersions of dipalmitoylphosphatidylcholine (DPPC) ? multilayer lamellar structures consisting of phospholipid bilayers separated by water layers, which imitate phospholipid membranes. BQAC decamethoxinum and aethonium were introduced separately or in combination with DHB. It should be noted that DHB was chosen as a compound modelling the acid and aromatic groups present in a number of amino acids [5]. The main method of investigation was differential scanning calorimetry (DSC) allowing determining changes in the calorimetric parameters of phase transitions in the model membranes when they are affected by membranotropic agents (MTA).

Materials and Methods. The DSC studies were carried out using the Mettler TA 3000 thermoanalytic system (Switzerland). Samples of 15-25 mg were placed into aluminium crucibles with half-closed lids. Programmed scheme of temperature scanning consisted of consecutive cycles of heating and cooling with the rate of $2 \mathrm{~K} / \mathrm{min}$.

Crystalline DPPC and BQAC were mixed and water dispersions of this composition with mass ratio DPPC: water of 50:50 [were prepared] using the standard method, described in [6]. While introducing BQAC and DHB simultaneously, we chose the concentrations to ensure the ratio between quaternary groups and DHB as $2: 1,1: 1$, and $1: 2$, corresponding to the molar ratios of $1: 1,1: 2$, and $1: 4$. The investigation of all the systems was performed at $\mathrm{pH} \mathrm{7,} \mathrm{the} \mathrm{total}$ amount of MTA, introduced into phospholipid matrix, was 5\% (mass).

The investigation by matrix-assisted laser desorption/ionization (MALDI) mass-spectrometry was performed using a time-of-flight mass spectrometer MALDI-TOF AutoFlex (Bruker Daltonics, Germany). In these experiments, one of the components of investigated systems, namely, DHB, functioned also as a UV-absorbing matrix for MALDI.

Preparations of DPPC (5.45\% humidity) of Alexis Biochemicals (Switzerland) and 2, 5-dihydroxybenzoic acid of Sigma (Germany) were 
Parameters of phase transitions for systems of hydrated DPPC + MTA

\begin{tabular}{c|c|c|c|c|c}
\hline \multirow{2}{*}{$\begin{array}{c}\text { Composition of } \\
\text { membranotropic agents }\end{array}$} & \multicolumn{2}{|c|}{ Heating } & \multicolumn{2}{c|}{ Cooling } & $\begin{array}{c}\text { Hyste- } \\
\text { resis }\end{array}$ \\
\cline { 2 - 6 } & $T_{m},{ }^{\circ} \mathrm{C}$ & $\begin{array}{c}\Delta H, \\
\mathrm{~J} / \mathrm{g}\end{array}$ & $T_{m},{ }^{\circ} \mathrm{C}$ & $\begin{array}{c}\Delta H_{\mathrm{m}}, \\
\mathrm{J} / \mathrm{g}\end{array}$ & $\Delta T,{ }^{\circ} \mathrm{C}$ \\
\hline no MTA & 41,5 & 23,4 & 41,4 & 40,3 & 0,1 \\
DHB & 37,1 & 20,3 & 36,1 & 23,9 & 1,0 \\
Decamethoxinum & 35,7 & 15,8 & 35,2 & 24,5 & 0,5 \\
$\begin{array}{c}\text { Decamethoxinum:DHB } \\
1: 1\end{array}$ & 37,9 & 15,3 & 35,0 & 26,0 & 2,9 \\
Decamethoxinum:DHB & 41,8 & 15,8 & 40,5 & 17,7 & 1,3 \\
$1: 2$ & & & & & \\
Decamethoxinum:DHB & 41,7 & 24,5 & 41,5 & 5,0 & 0,2 \\
$1: 4$ & & & & & \\
Aethonium & 39,8 & 17,8 & 39,7 & 18,5 & 0,1 \\
Aethonium:DHB 1:1 & 40,0 & 13,7 & 39,5 & 16,6 & 0,5 \\
Aethonium:DHB 1:2 & 41,6 & 17,8 & 40,2 & 21,7 & 1,4 \\
Aethonium:DHB 1:4 & 41,6 & 18,8 & 40,9 & 30,8 & 0,7 \\
\hline
\end{tabular}

used in the work. Decamethoxinum and aethonium were synthesized in the Institute of Organic Chemistry, NAS of Ukraine.

Results and Discussion. The formation of stable non-covalent complex of BQAC decamethoxinum dication with DHB anion was registered in the conditions of MALDI mass-spectrometry experiment using solid samples obtained from dried water solution of decamethoxinum and DHB (Fig.2). Along with the dication associate with one chloride anion $\mathrm{Cat}^{+2} \cdot \mathrm{Cl}^{-}$, $m / z$ 657, characteristic ion in mass-spectra of pure decamethoxinum [2], the dication associate with DHB anion $\mathrm{Cat}^{2+} \cdot(\mathrm{DHB}-\mathrm{H})^{-}, \mathrm{m} / \mathrm{z} 775$ is formed. At equimolar ratio of components in initial solution, the intensity of associate $\mathrm{Cat}^{2+} \cdot(\mathrm{DHB}-\mathrm{H})$ in MALDI mass-spectra is considerably higher than that of associate $\mathrm{Cat}^{2+} \cdot \mathrm{Cl}^{-}$, which indicates the competition between anions and predominate binding of organic anion to dication (DHB-H)

DSC method was used to determine the calorimetric parameters of phase transitions in model membranes in the range of physiological temperatures, namely, transition from gel phase into liquid crystalline

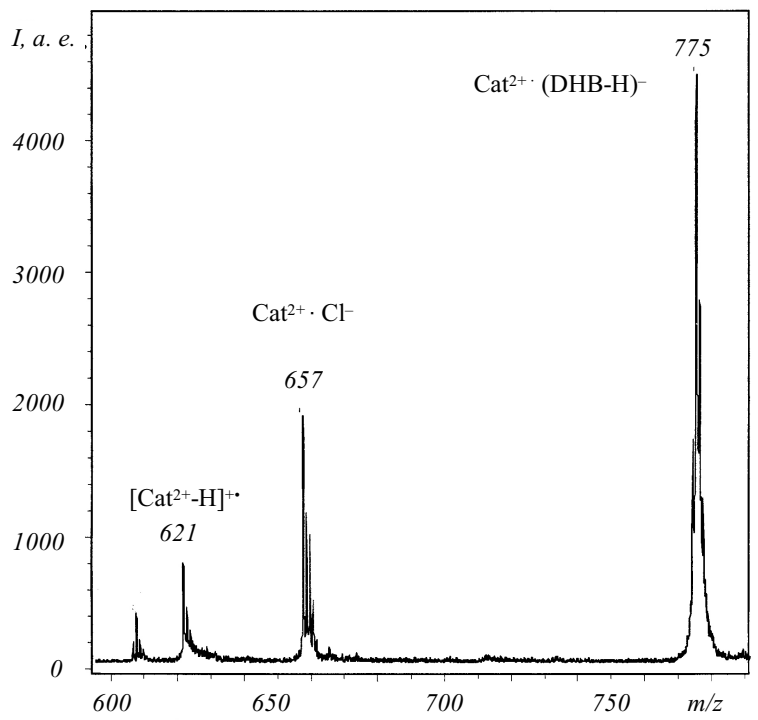

Fig. 2. Part of MALDI mass-spectrum of decamethoxinum sample in DHB matrix containing dication associates of decamethoxinum with chloride anion $\mathrm{Cat}^{+2} \cdot \mathrm{Cl}^{-}$and anion of deprotonated DHB $\mathrm{Cat}^{2+} \cdot(\mathrm{DHB}-\mathrm{H})^{-}$

state. The study was performed on water dispersions of DPPC alone, DPPC with addition of BQAC of decamethoxinum, aethonium, and $\mathrm{DHB}$, and mixtures of BQAC: and DHB . Table 1 presents the data of DSC: temperature $\left(T_{m}\right)$ and enthalpy $\left(\Delta H_{m}\right)$ of the main phase transition, determined in the regimes of heating and cooling, as well as hysteresis $(\Delta T)$.

To solve the question about stoichiometry of possible complexes, we analyzed the initial data using the method of quasibinary systems [7, 8]. In this method, the phospholipid medium is considered as a matrix, in which two dissolved components interact. In the absence of interaction, any thermodynamic feature of the system, expressed in corresponding units, is additive with respect to the relative concentrations of components and vice versa, specific interaction results in a deviation from the additivity.

Fig. 3 presents quasibinary phase diagrams for the systems containing hydrated DPPC with additions of BQAC of decamethoxinum and aethonium, as well as DHB acids. The straight line connecting two extreme points corresponding to $T_{m}$ of BQAC and DHB relates to the diagram in case of $T_{m}$ additivity. The length of the perpendicular dropped from the maximum of the experimental curve on this line characterizes the deviation from additivity; the location of the curve 

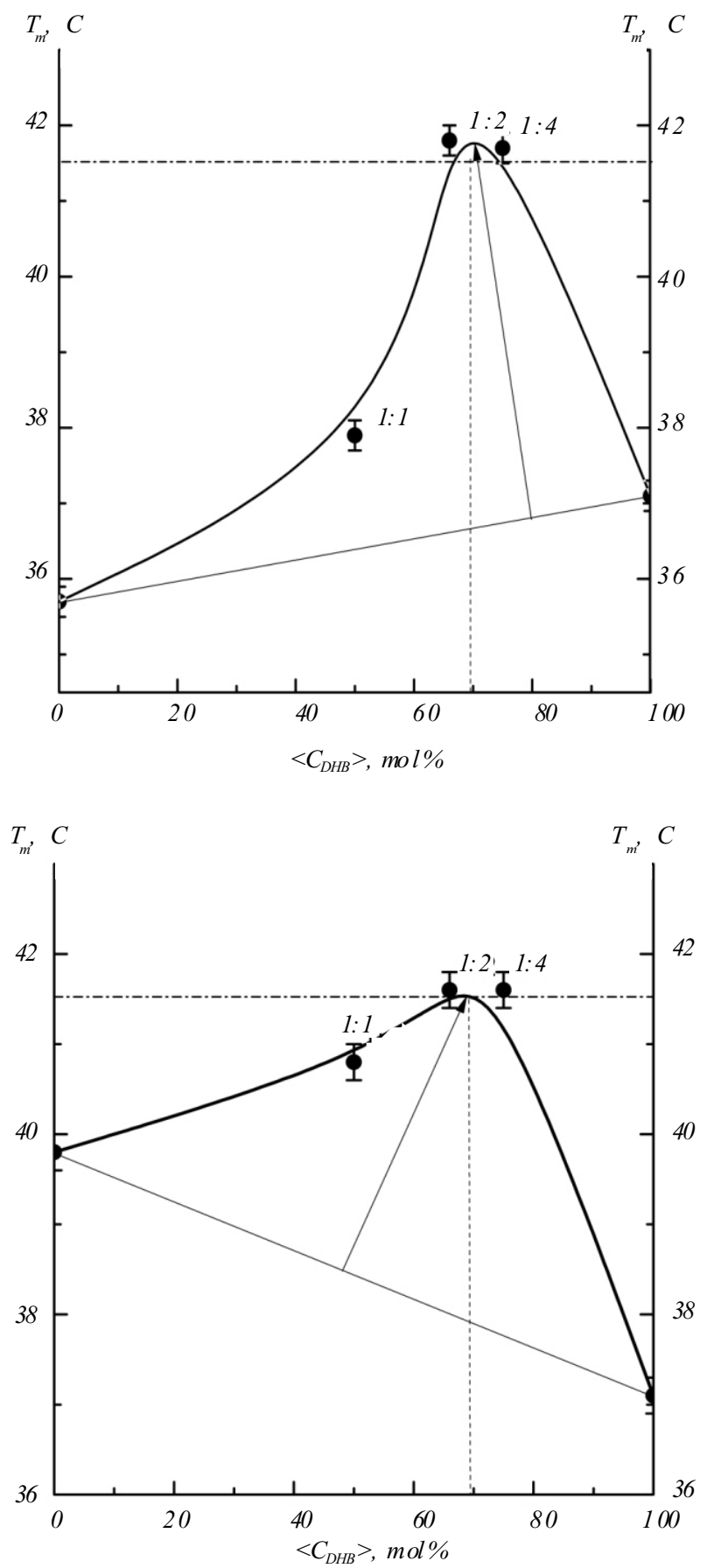

Fig. 3. Phase diagrams of quasibinary systems: decamethoxinum-DHB $(a)$, aethonium-DHB $(b)$ in the medium of hydrated DPPC (total MTA concentration in all the systems is 5 mass. \%). Corresponding molar ratios of MTA are indicated in markings of experimental points

maximum points to the most advantageous stoichiometry of the complexes incorporated into the membrane.
The analysis of the data obtained gives grounds for the following conclusions. The change in thermodynamic parameters of model membranes at introducing individual MTA into the water dispersion of DPPC proves the interaction of all investigated MTA with phospholipid bilayers. The introduction of MTA considerably decreases the temperature of the main phase transition, i.e. it results in disorder of phospholipid bilayers. As quaternary ammonium compounds and DHB acid dissociate in water solution, it is possible to suppose that these MTA are built into the membrane in the form of ions: dications of decamethoxinum and aethonium $\mathrm{Cat}^{2+}$ and anion (DHB-H) .

Simultaneous introduction of BQAC and DHB into DPPC dispersion also changes its thermodynamic parameters, but there is no observed additivity of BQAC and DHB effects related to the concentration of introduced components. A considerable deviation from additivity in systems (DPPC + BQAC + DHB) is an evidence of specific interaction between the additives introduced into phospholipid matrix. The complexes of BQAC and DHB are likely to be formed similarly to the complexes of $\mathrm{Cat}^{2+} \cdot(\mathrm{DHB}-\mathrm{H})$ - registered in the mass-spectrometry experiment ([see] Fig.2) due to Coulomb interaction between corresponding cations and anions.

Plotting of quasibinary diagrams allowed determining the stoichiometry of complexes BQAC: DHB 1:2, which is notable for the maximal deviation from additivity ([see] Fig.3). In these complexes one DHB anion corresponds to each ammonium group in the composition of BQAC.

The degree of effect of simultaneously introduced BQAC and DHB on the system calorimetric parameters significantly depends on the ratio between components. If molar ratio BQAC to DHB is $1: 1, T_{m}$ values for the three-component system (DPPC + $\mathrm{BQAC}+\mathrm{DHB}$ ) do not differ much from those for the binary system (DPPC + BQAC). If BQAC ratio to DHB is $1: 2$ and $1: 4$, there are qualitative changes: a shift of the main transition temperature changes the sign with respect to $T_{m}$ of non-doped DPPC; however, an increase in $T_{m}$ absolute value is insignificant. This effect may be considered as elimination of disordering influence of BQAC on membranes in the presence of 
definite DHB concentrations. Therefore, it is possible to regard DHB as a modulator of BQAC activity. On the other hand, complex formation with BQAC decreases the DHB activity.

Neutralization of the charge of BQAC dication while forming its complex with DHB seems to be the most probable molecular mechanism of the abovementioned effect of modulation of the BQAC activity. This assumption is based on the fact that the transition from decrease to increase in melting temperature $T_{m}$ in the system (DPPC $+\mathrm{BQAC}+\mathrm{DHB}$ ) occurs at the DHB content that either equals or exceeds the amount of positively charged ammonium groups (two groups per one BQAC molecule), which is sufficient for their neutralization at the complex formation. If molecular ratio $\mathrm{BQAC}$ to $\mathrm{DHB}$ is $1: 1$, one of the dication positive centres on average is not "compensated" by DHB anion and the calorimetric parameters still change in accordance with the effect of ion MTA on the membrane.

It should be noted that previously we described the dependence of membranotropic activity of the BQAC-based surfactants on their structure, i.e. the nature of hydrophobic "tail" and a distance between positively charged atoms of quaternary nitrogen, on the example of decamethoxinum and aethonium $[2,3]$. The structure of aethonium dication, including a polar "head" of two closely located ammonium groups and two hydrophobic carbohydrate chains, is generally similar to the structure of DPPC molecules, which provides the building of aethonium dication into the membrane due to the substitution of DPPC molecule. A more complicated structure of hydrophobic "tails" of decamethoxinum, containing methyl residues, as well as rather large distance between positively charged ammonium groups result in greater destabilizing effect of decamethoxinum on the membranes in comparison to aethonium.

As for enthalpy values of the main phase transition in model membranes determined in the regime of sample heating, they demonstrate a general tendency to decreasing when MTA is introduced into the system. At first sight, this fact shows that disordering of membranes requires much less energy in the presence of destabilizing agents in their composition. The processes occurring during cooling of the system are re- lated to the peculiarities of MTA inclusion into the liquid crystal structure of membranes, which is a subject of further studies beyond the framework of this review.

Conclusions. The possibility of modulation of the activity of MTA, based on BQAC salts, was considered for the case of their simultaneous with organic acid DHB introduction into the model phospholipid membranes.

The data of DSC research demonstrated the absence of additivity of calorimetric parameters, which is a characteristic of the model membranes containing individual MTA, in the case of simultaneous introduction of the mixture of DHB with BQAC decamethoxinum and aethonium into the water dispersion of hydrated DPPC. This experimental fact evidences the insertion of MTA complexes instead of individual MTA into the membranes.

The data of mass-spectrometry showed the possibility of formation of stable complexes of cations of quaternary ammonium compounds with DHB anion.

The analysis of calorimetric parameters of the systems investigated revealed that the insertion of dissociated in solution individual components in ionic state into the membranes, results in a decrease in the temperature of main transition and corresponding disordering of the membrane structure. The similar effect of decrease in the membrane melting temperature is observed if components of the MTA mixtures added are in the ratio sustaining a charged state of their complexes. In case of the formation of neutral complexes of BQAC dications with DHB anion, an increase in the temperature of main transition is revealed along with ordering the membrane structure. This effect may be considered as BQAC deactivation, i.e. modulation of the BQAC activity by organic acid. Neutralization of ionic MTA due to the formation of cation-anion complexes was suggested as a molecular mechanism of such modulation.

The possibility of weakening membranotropic activity of the BQAC-based antimicrobial agents, revealed at their introduction together with organic acid, should be taken into account while developing polycomponent drugs of antimicrobial activity. The approach proposed in this work may be used on a broader scale for testing the combined activity of MTA of various nature. 
О. В. Ващенко, В. А. Пашинская ${ }^{1}$, М. В. Косевич ${ }^{1}$, В. Д. Паникарская, Л. Н. Лисечкий

Модуляция воздействия четвертичных аммониевых соединений на модельные биомембраны посредством комплексообразования с органическим анионом

Институт сцинтилляционных материалов НТК «Институт монокристаллов» НАН Украины

Проспект Ленина, 60, Харьков, Украина, 61001

${ }^{1}$ Физико-технический институт низких температур

им. Б. И. Веркина НАН Украины

Проспект Ленина, 47, Харьков, Украина, 61103

Резюме

Цель. Изучить модуляцию мембранотропной активности бисчетвертичных аммониевых соединений (БЧАС) декаметоксина $и$ этония, обусловленную их взаимодействием $c$ органическим анионом дигидроксибензойной кислоты (DHB). Методы. Дифференциальная сканирующая калориметрия, масс-спектрометрия. Результаты. Обнаружено, что добавление индивидуальных БЧАС или DНВ к фосфолипидным мембранам значительно снижает температуру перехода «гель-жидкий кристалл». При совместном введении БЧАС и DНВ температура фазового перехода мембраны несколько повышается, что свидетельствует об отсутствии аддитивности действия этих веществ и встраивании в мембраны их комплексов. Выводы. DHВ уменьшаает эффективность дестабилизирующего эффекта БЧАС на мембраны, то есть является модулятором их активности. Возможный молекулярный механизм модулячии заключается в компенсации зарядов дикатиона БЧАС и органических анионов DНВ при образовании их комплекса, взаимодействие которого с мембранными структурами отличается от такового ионных форм индивидуальных соединений.

Ключевые слова: мембранотропные агенты, фосфолипидные мембраны, бисчетвертичные аммониевые соединения, дигидроксибензойная кислота, модуляция активности, дифференииальная сканирующая калориметрия.

О. В. Вашенко, В. А. Пашинська, М. В. Косевич,

В. Д. Панікарська, Л. М. Лисецький

Модуляція впливу бісчетвертинних амонієвих сполук на модельні біомембрани внаслідок комплексоутворення 3 органічним аніоном

\section{Резюме}

Мета. Вивчити модуляцію мембранотропної активності бісчетвертинних амонієвих сполук (БЧАС) декаметоксину та етонію, зумовлену їхньою взаємодією з органічнім аніоном дигідроксибензойної кислоти (DHB). Методи. Диферениійна скануюча калориметрія, мас-спектрометрія. Результати. Виявлено, щяо додавання індивідуальних БЧАС або DНВ до фосфоліпідних мембран значно знижує температуру фазового переходу «гель-рідкий кристал». При одночасному введенні БЧАС $i$
DHВ температура фазового переходу мембрани дещо підвищується, що свідчить про відсутність адитивності діі иих речовин та інкорпорацію у мембрани утворених ними комплексів. Висновки. DНВ змениує ефективність дестабілізувальної дї̈ БЧАС на мембрани, тобто слугує модулятором їхньої активності. Ймовірний молекулярний механізм модуляиії полягає у компенсаиії зарядів дикатіона БЧАС та органічних аніонів DHВ при утворенні їхнього комплексу, взаємодія якого з мемб- ранними структурами є відмінною від такої іонних форм інди-відуальних сполук.

Ключові слова: мембранотропні агенти, фосфоліпідні мембрани, бісчетвертинні амонієві сполуки, дигідроксибензойна кислота, модуляція активності, диференційна скануюча калориметрія.

\section{REFERENCES}

1. Vievskij A. N. Cationic surfactants: New perspectives in medicine and biology // Tenside, Surfactants, Detergents.1997.-34, N 1.-P. 18-21.

2. Pashynskaya V. A., Kosevich M. V., Gomory A., Vashchenko $O$. V., Lisetski L. N. Mechanistic investigation of the interaction between bisquaternary antimicrobial agents and phospholipids by liquid secondary ion mass spectrometry and differential scanning calorimetry // Rapid Commun. Mass Spectrom.-2002.-16, N 18.-P. 1706-1713.

3. Korzovskaya O. V., Pashinskaya V. A., Kosevich M. V., Lisetski L. N. Interaction of antimicrobial agents decamethoxinum and aethonium with model membranes // Proc. Kharkiv State Univ., Biophys. Bull.-1999.-450, N 2.-P. 35-39.

4. Pashynska V. A., Kosevich M. V., Van den Heuvel H., Cuyckens $F$., Claeys $M$. Study of non-covalent complexes formation between the bisquaternary ammonium antimicrobial agent decamethoxinum and membrane phospholipids by electrospray ionization and collision-induced dissociation mass spectrometry // Proc. Kharkiv State Univ., Biophys. Bull.-2004.-637, N 1-2 (14).- P. 123-130.

5. Pahynska V., Kosevich M., Stepanian S., Adamowicz L. Noncovalent complexes of tetramethylammonium with chlorine anion and 2,5-dihydroxybenzoic acid as models of the interaction of quaternary ammonium biologically active compounds with their molecular targets. A theoretical study // J. Mol. Struct.: THEOCHEM.-2007.-815, N 1-3.-P. 55-62.

6. Korzovskaya O. V., Lisetski L. N., Panikarskaya V. D. UVspectroscopy and structura features of model membranes and liquid-crystalline biomimetic systems // Proc. Kharkiv State Univ., Biophys. Bull.-1998.-422, N 2.-P. 85-89.

7. Fialkov Yu. Ya., Zhitomirskij A. N., Tarasenko Yu. A. Physical chemistry of non-aqueous solution.-Leningrad: Khimiya, 1973.-376 p.

8. Solutions of non-electrolytes in liquids.-Moskva: Nauka, 1989.-264 p.
UDC $577.352 \cdot 615.2$

Received 29.03.10 